\title{
MIR200C wt Allele
}

National Cancer Institute

\section{Source}

National Cancer Institute. MIR200C wt Allele. NCI Thesaurus. Code C82157.

The human MIR200C wild-type allele is located in the vicinity of 12p13.31 and is approximately 67 bases in length. This allele, which encodes MIR200C pre-miRNA, plays a role in the regulation of gene expression. Alteration in the expression of this gene is associated with development of breast cancer. 